\title{
Assessment of alterations in some blood biochemical and mineral contents concentration before and during pregnancy period in Iraqi ewes of Salah-edin province
}

\author{
M.A. Ismaeel*, A.H. Awad and N.N. Dhahir \\ Department of Medicine, Surgery and Obstetrics, College of Veterinary Medicine, Tikrit University, Tikrit, Iraq \\ *Email: dr.maythem.ir.78@tu.edu.iq
}

(Received October 12, 2017; Accepted July 29, 2018)

\begin{abstract}
Thirty local Iraqi ewes reared in Tikrit - Salah-edin province from first the of October-2016 to the first of March-2017 were used in the current study to investigate the influence of pregnancy on levels of some biochemical and minerals contents in the blood serum. Blood samples were collected from ewes before and monthly during pregnancy (first, second, third, fourth and fifth month), serum separated and stored at $5{ }^{\circ} \mathrm{C}$ until samples analysis. All samples were analyzed by spectrophotometer with special kits for each parameter. Results demonstrate significant decrease $(\mathrm{P} \leq 0.05)$ in concentration of total protein, cholesterol and glucose as pregnancy advanced, while there is no effect of pregnancy on the concentration of creatinine and magnesium, however, there is a significant increase $(\mathrm{P} \leq 0.05)$ in calcium concentration as pregnancy proceed. In conclusion the pregnancy has clear influences on the concentration of total protein, cholesterol, glucose and calcium. The measurements of these parameters give best assessment for nutritional and health status of Iraqi ewes during pregnancy.
\end{abstract}

Keywords: Biochemical, Pregnancy, Local ewes, Mineral, Embryo development

Available online at http://www.vetmedmosul.org/ijvs

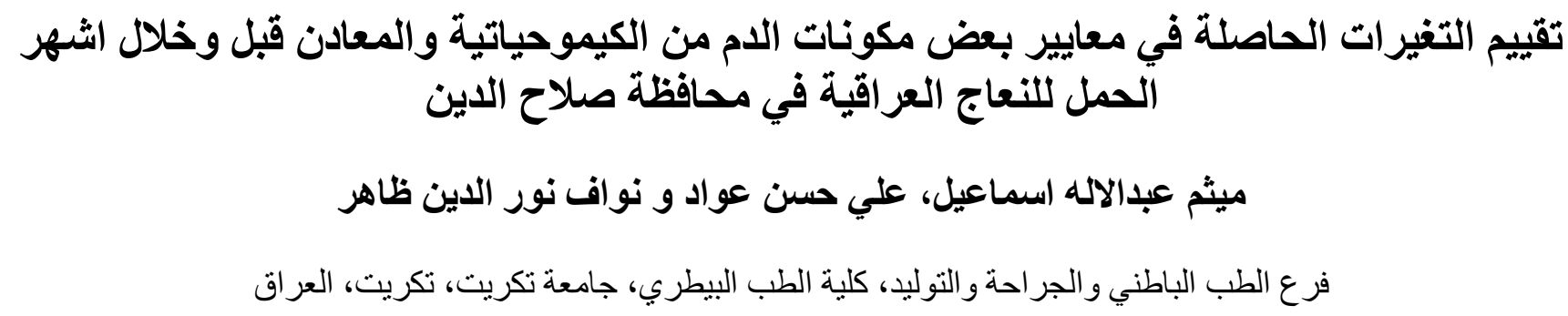

الخلاصة

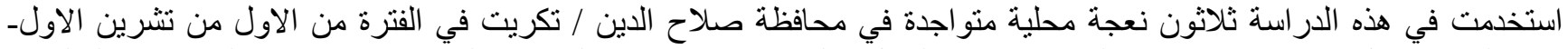

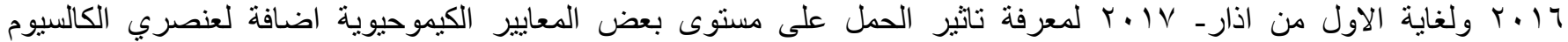

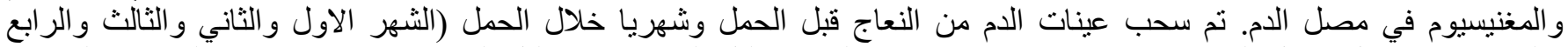

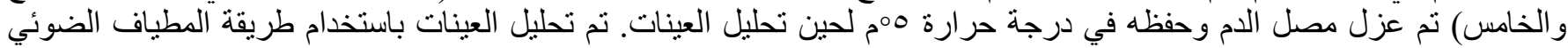

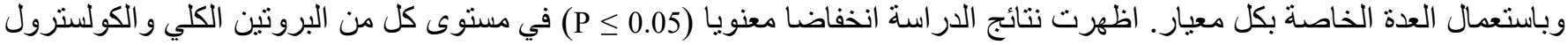

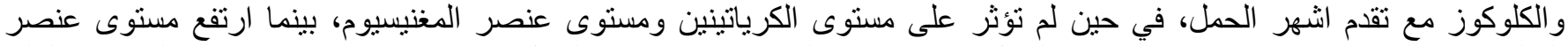

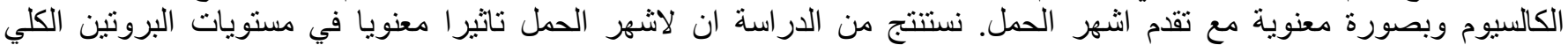

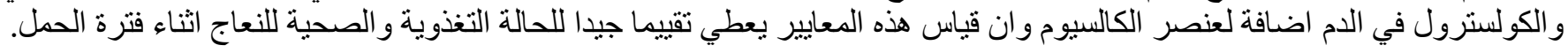




\section{Introduction}

Pregnancy considered as a one of the important physiological period during the female life which causes stress on the body and stimulates an alternative mechanism to maintain the natural homeostasis during pregnancy (1). The increased requirements of nutrition for fetal development lead to various metabolic changes in animal body (2-4). This changes that occurred in the biochemical and minerals are not only due to state of nutrition but breed, age, sex of embryo and reproductive status of dam like pregnancy are involved $(5,6)$. Many alterations in mother body's composition, the contents of dietary energy and the metabolism occur during pregnancy are served to provide food for fetal development (7), these changes in turn alternate the chemical parameters of the blood serum contents $(8,9)$. The biochemical parameters in blood, such as total protein and cholesterol are of the most important criteria which can be used to measure the metabolic state of animal energy in advanced pregnancy and lactation (10). Clear reductions in both glucose and cholesterol as well as total protein in the last period of pregnancy are found by (11).

Glucose is one of the most important sources of energy for reproductive function and production, its considered most important material utilized by fetuses in sheep during pregnancy (12), the requirements of energy in sheep are increased in the last period of pregnancy due to rapid increase in fetal growth (13), while cholesterol levels tend to decrease as pregnancy progresses (14-17). Creatinine is muscular byproducts metabolites and excreted from blood through kidney, so its level in blood is considers as a good indicator for measurement of kidney efficiency $(18,19)$. Body bone tissue is the main storage of calcium, and its remobilization occurs near the end of pregnancy to maintain its blood level, in which, it is necessary for the ossification process of skeletal bone in fetus (20).

It is an important issue to know the natural levels of some biochemical and minerals and propagated an indicator for the normal and pathological condition during pregnancy in ewes, so this study was designed to determine the normal concentration of total protein, cholesterol, glucose and creatinine, as well as the calcium and magnesium elements in blood serum during different gestational period in local ewes.

\section{Materials and methods}

\section{Experiment animals and blood collection}

Thirty local ewes were used in this study aged 2-4 years, reared in Tikrit - Salah -edin province from the first of October-2016 to the first of March-2017, blood samples were taken from ewes in the period before and monthly during Pregnancy (1st, 2nd, 3rd, 4th and 5th month of pregnancy, respectively) by jugular vein aseptical aspiration. Blood samples were directly collected in tubes without anticoagulation, left for twenty minutes settlement at room temperature, then preserved in the refrigerator for 24 hours. Serum extracted by samples centrifugation (3000 $\mathrm{rpm}$ ), for $10 \mathrm{~min}$ stored at $-20^{\circ} \mathrm{C}$ until the time of analysis.

\section{Biochemical analysis}

Serum concentration of total protein, cholesterol, glucose, creatinine, as well as calcium and magnesium were conducted by spectrophotometer (21) with special kit (Biomeghrib Company, Maghrib) for each parameter in the clinical pathology Lab., at collage veterinary medicine, University of Tikrit.

\section{Statistical analysis}

The stigma stat program was used for the data analysis and finds the average and standard error, as well as the significant differences between the pre-pregnancy period and each month of pregnancy according to Friedman Repeated Measures Analysis of Variance on Ranks.

\section{Results}

Results in Table (1), showed that the most biochemical parameters in the ewes serum were significantly decreased $(\mathrm{P} \leq 0.05)$ during pregnancy as compared before pregnancy period. The concentration of total protein was significantly decreased as pregnancy advanced starting from third month and continues to fourth and last month $(5.54 \pm 0.09$, $5.71 \pm 0.25$, and $4.25 \pm 0.23 \mathrm{~g} / 1$ respectively), compared before pregnancy period $(0.3 \pm 7.73 \mathrm{~g} / 1)$, while the concentration of cholesterol was decreased $(\mathrm{P} \leq 0.05)$ earlier then gradual through pregnancy period toward the last month $(53.08 \pm 2.49,52.43 \pm 2.59,52.03 \pm 1.46,50.86 \pm 1.8$, $50.74 \pm 0.95 \mathrm{mg} / \mathrm{dl}$ for each month respectively) as compared before pregnancy period $(67.95 \pm 2.17 \mathrm{mg} / \mathrm{dl})$.

Glucose concentration was significantly decreased $(\mathrm{P} \leq 0.05)$ as pregnancy progressed starting from the first to last month of pregnancy $(82.2 \pm 1.49,70.4 \pm 2.88,65.4 \pm$ $2.5,63 \pm 1.35,46.4 \pm 1.04 \mathrm{mg} / \mathrm{dl}$ respectively) as compared before pregnancy $(40.6 \pm 2.07 \mathrm{mg} / \mathrm{dl})$, and this diminution in glucose level was higher in the last two months as compared with the other period (Table 1).

Results showed no differences in creatinine serum concentration before pregnancy period $(0.97 \pm 0.15 \mathrm{mg} / \mathrm{dl})$ and during the five months of gestation $(0.18 \pm 0.03,0.14 \pm$ $0.02,0.11 \pm 0.005,0.34 \pm 0.22,0.36 \pm 0.15 \mathrm{Mg} / \mathrm{dl}$, respectively).

Calcium concentration was showed in Figure (1) this concentration in pregnant ewes was significantly $(\mathrm{P} \leq 0.05)$ increased compared with non-pregnant period $(8.81 \pm 0.66$ 
$\mathrm{mg} / \mathrm{dl}$ ) and this increasing was continued as pregnancy preceded to reach maximum value in last month of pregnancy $(11.48 \pm 0.28 \mathrm{mg} / \mathrm{dl})$, while, the concentration of magnesium did not show any significant differences between any periods (Figure 2).

Table 1: Changes in the concentration of biochemical parameters before and during different months of pregnancy in ewes $($ mean \pm SE)

\begin{tabular}{lcccccc}
\hline \multirow{2}{*}{ Parameter } & \multicolumn{5}{c}{ Period } \\
\cline { 2 - 7 } & Pre-pregnancy period & $1^{\text {st }}$ month & $2^{\text {nd }}$ month & $3^{\text {rd }}$ month & $4^{\text {th }}$ month & $5^{\text {th }}$ month \\
\hline Total protein $(\mathrm{g} / \mathrm{l})$ & $7.73 \pm 0.3 \mathrm{~A}$ & $7.51 \pm 0.14 \mathrm{~A}$ & $6.08 \pm 0.11 \mathrm{~A}$ & $5.54 \pm 0.09 \mathrm{~B}$ & $5.71 \pm 0.25 \mathrm{~B}$ & $4.25 \pm 0.23 \mathrm{~B}$ \\
Cholesterol $(\mathrm{mg} / \mathrm{dl})$ & $67.95 \pm 2.17 \mathrm{~A}$ & $53.08 \pm 2.49 \mathrm{~B}$ & $52.43 \pm 2.59 \mathrm{~B}$ & $52.03 \pm 1.46 \mathrm{~B}$ & $50.86 \pm 1.8 \mathrm{~B}$ & $50.74 \pm 0.95 \mathrm{~B}$ \\
Glucose $(\mathrm{mg} / \mathrm{dl})$ & $82.2 \pm 1.49 \mathrm{~A}$ & $70.4 \pm 2.88 \mathrm{C}$ & $65.4 \pm 2.5 \mathrm{C}$ & $63 \pm 1.35 \mathrm{C}$ & $46.4 \pm 1.04 \mathrm{~B}$ & $40.6 \pm 2.07 \mathrm{~B}$ \\
Creatinine $(\mathrm{mg} / \mathrm{dl})$ & $0.97 \pm 0.15 \mathrm{~A}$ & $0.18 \pm 0.03 \mathrm{~A}$ & $0.14 \pm 0.02 \mathrm{~A}$ & $0.11 \pm 0.05 \mathrm{~A}$ & $0.34 \pm 0.22 \mathrm{~A}$ & $0.36 \pm 0.15 \mathrm{~A}$ \\
\hline
\end{tabular}

Different letters between columns mean significant differences at $(\mathrm{P} \leq 0.05)$.

\section{calcium concentrat}

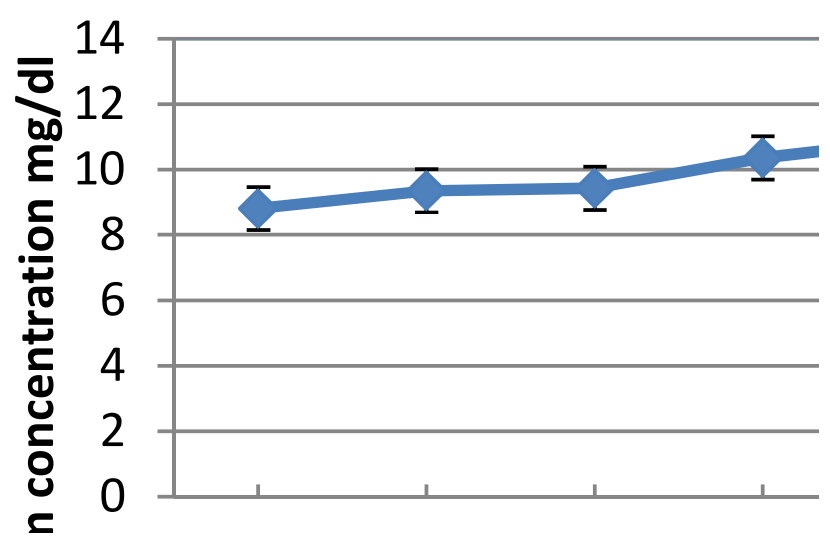

Figure 1: Calcium concentrations changes in non-pregnant period and during pregnancy in ewes.

\section{$\sim$ magnesium.}

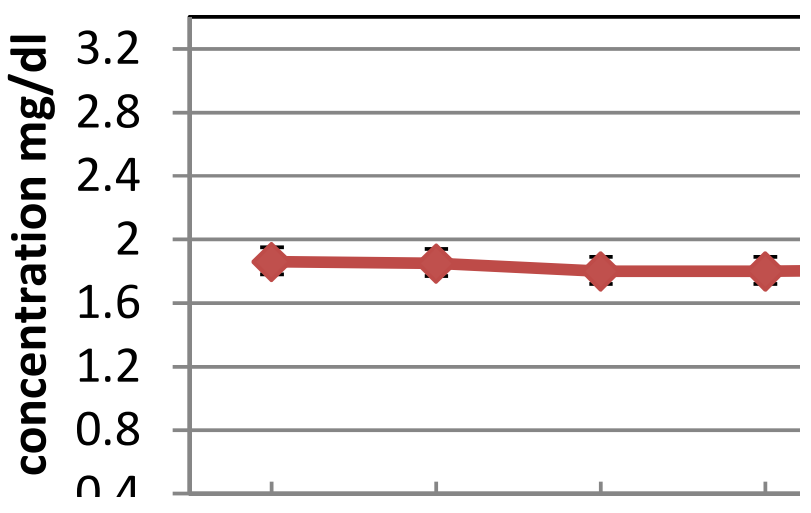

Figure 2: Magnesium concentrations changes in nonpregnant period and during pregnancy in ewes.

\section{Discussion}

The results showed that pregnancy had a clear effect on some serum biochemical criteria in the local ewes (Table 1). Total protein level was significantly decreased from the $3^{\text {th }}$ to $5^{\text {th }}$ month of pregnancy compared to the non-pregnant period, This result was agreed with (22-24), that this decreasing is due to embryonic growth, which in turn leads to consumption of large amounts of Amino acids from the mother to maintain fetal protein and muscles development $(6,23)$. Uterine growth during pregnancy to compensate fetal growth requires utilization a large amount of protein (25). Producing the immunoglobulin from blood plasma during last month and before birth when the formation of the colostrum in the mammary gland presents (26). These results was not agree with (27), who was not notice any effect of pregnancy on the concentration of total protein, and with $(16,28)$ who observed a significant increase in total protein concentration as gestation progress in ewes. This may be due to the effect of age and season on total protein concentration in ewes $(23,29)$.

Effect of Pregnancy on blood cholesterol concentration, demonstrated by a significant decrease in the level of cholesterol as pregnancy proceed compared to its level in non-pregnancy period, this result was compatible with $(2,16)$, these outcomes may due to increased use of cholesterol during pregnancy to utilize steroid hormones needed to sustain pregnancy and develop lactation at the end of pregnancy $(30,31)$.

Level of glucose in the blood serum of pregnant ewes had decreased significantly as pregnancy progresses, this may be due to increased metabolism of glucose by the fetus during its development in the uterus and its transmission from the mother to the circulatory system of the fetus (1), this findings are confirmed with (32-37).

There is no change in level of creatinine in the serum of ewes during pregnancy compared to non-pregnancy period, and this corresponds to $(9,34,38)$ while they did not agree 
with (22) who observed a significant increase in their level with progression of pregnancy, this may be due to differences in the breed or to the health status of animals during study.

Effect of pregnancy upon calcium concentration showed in (Figure 1), a clear effect of pregnancy on calcium concentration, with a significant increase in concentration as the gestation period advanced in local ewes. This is consistent with (39), this increase was due to increased fetal tissue requirements, thus increasing the absorption of calcium from the digestive system of pregnant ewes or to increase the secretion of parathyroid hormone as the pregnancy progresses then activates osteoclasts and thus increases the level of calcium in the blood (40), to maintain fetal skeleton requirements (41), While the results (Figure 2) did not showed any effect of pregnancy on blood concentration of magnesium in the local ewes.

We conclude from the study that pregnancy has a clear effect on the concentration of total protein, cholesterol and glucose in addition to the calcium element in blood of local ewes, and these parameters provide a good assessment of the nutritional status and health of pregnant sheep.

\section{Reference}

1. Jacob N, Vadodaria VP. Levels of glucose and cortisol in blood of Patanwadi ewes around parturition. Ind Vet J. 2001;78:890-892.

2. Krajnicakova M, Bekeova E, Heindrichovsky V, Maracek I. Concentrations of total lipids, cholesterol and progesterone during oestrus synchronization and pregnancy in sheep. Vet Med. 2003:38:349-357.

3. Iriadam M. Variation in certain hematological and biochemical parameters during the peripartum period in Kilis does. Small Rum Res. 2007;73:54-57.

4. Sobiech P, Milewski S, Zduńczyk S. Yield and composition of milk and blood biochemical components of ewes nursing a single lamb or twins. Bull Vet Inst Pulawy. 2008;52:591-596.

5. ARC. The nutrient requirements of ruminant livestock, commonwealth agricultural al Bureaux, Farnham Royal, Slough. 1980.

6. Balikci E, Yildiz A, Gurdogan F. Blood metabolic concentrations during pregnancy and postpartum in Akkaraman ewes. Small Rum Res. 2007;67:247-251.

7. Owens JA. Endocrine and substrate control of fetal growth, placental, maternal influences and insulin-like factors. Rep Fertil Dev. 1991;3:501-511.

8. Swanson KS, Kuzmuk K N, Schook LB, Fahey GC. Diet affects nutrient digestibility, hematology, and serum chemistry of senior and weanling dogs. J Anim Sci. 2004;82:1713-1724.

9. Yokus BD, Cakir Z, Kanay T, Gulten U, Uysal E. Effects of seasonal and physiological variations on the serum chemistry, vitamins and thyroid hormone concentrations in sheep. J Vet Med. 2006;53:271276.

10. Hatfield PG, Head WA, Fitzgerald JA, Hallford DM. Effect of level energy intake and energy demand on growth hormone, insulin, and metabolites in Targhee and Suffolk ewes. J Anim Sci. 1999;77:27572765.

11. El-Din IMG, El-Sangery FHO. Clinical and biochemical studies of pregnancy toxemia in sheep in Shakira Governorate. Assiut Vet Med J.2005;51;(105):141-151.
12. Radostits OM, Gay CC, Blood DC, Hinchcliff KW. Veterinary Medicine. 9th Ed, Harcourt Publishers Ltd., London. 2000;pp:14171420.

13. Firat A, Ozpinar A. Metabolic profile of pre pregnancy, pregnancy and early lactation in multiple lambing Sakiz ewes. 1. Changes in plasma glucose, 3- hydroxybutyrate and cortisol levels. Ann Nutr Metab. 2002;46(2):57-61.

14. Mufti AM. Studies on morphological characters and some metabolic constituents at different stages of development of ovine foetus. M.V.Sc. Thesis, Sher-e-kashmir University of Agricultural Sciences and Technology, Shalimar, Srinagar. 1995.

15. Nazifi S, Saeb M, Ghavami SM. Serum lipid profile in Iranian fat tailed sheep in late pregnancy, at parturition and during the postparturition period. J Vet Med Ser A. 2002;49:9-12.

16. Piccione G, Caola G, Giannetto C, Grasso F, Runzo SC, Zumbo A. Pennisi P. Selected biochemical serum parameters in ewes during pregnancy, post-parturition, lactation and dry period. Anim Sci Papers Rep. 2009;27(4):321-330.

17. Khatun A, Wani GM, Bhat JIA, Choudhury AR, Khan MZ. Biochemical indices in sheep during different stages of pregnancy. Asian J Anim Vet Adv. 2010;6:175-181.

18. Kamili A, Bengoumi M, Oukessou M, Faye B, Lefebvre HP. Assessment of glomerular filtration rate in normally hydrated and dehydrated dromedary camel by plasma exogenous creatinine clearance test. Emirates J Food Agric. 2013;25:314-319.

19. Patel SS, Molnar, M Z, Tayek JA, Ix JH, Noori N, Benner D, Heymsfield S, Kopple JD, Kovesdy CP, Kalantar-Zadeh K. Serum creatinine as a marker of muscle mass in chronic kidney disease:results of a cross sectional study and review of literature. J Cachexia Sarcopenia Muscle. 2013;4:19-29.

20. Payne AK, Duttagupta R, Maitra DN. Physiological studies on blood of goats. Ind Vet J. 1977;59:597-599.

21. Henry JB. Clinical Diagnosis and management 17th ed, Sauder's Publisher. 1984.

22. EL-Sherif MMA. Assad F. Changes in some blood constituents of Barki ewes during pregnancy and lactation under semi-arid conditions. Small Rumin Res. 2001;40:269-277.

23. Antunovic Z, Sencic D, Speranda M, Liker B. Influence of the season and the reproductive status of ewes on blood parameters. Small Rumin Res. 2002;45:39-44.

24. Gürgöze S, Abuzer KZ, Nihat Ö, Hasan I. Investigation of some biochemical parameters and mineral substance during pregnancy and postpartum period in Awassi ewes. Kafkas Univ Vet Fak Derg. 2009;15(6):957-963.

25. Vihan VS, Rai P. Certain hematological and biochemical attributes during pregnancy, parturition and post parturient periods in sheep and goats. Ind J Anim Sci.1987;57:1200-1204.

26. Kaneko JJ, Harvey JW, Bruss ML. Clinical Biochemistry of Domestic Animals. 6th ed. Elsevier/Academic Press, Amsterdam. 2008.

27. Gururaj PM, Veena M, Narayana Swamy MR, Jayashankar PT, Ramesh T, Shridhar NB. Studies on Certain Serum Metabolites in non-Pregnant and Pregnant Bannur Ewes. Theriogen Insight. 2014;4(1):1-7.

28. Barakat SEM, AL-Bhanasawi NM, Elazhari GE, Bakhiet AO. Clinical and seromiochemical studies on naturally-occurring pregnancy toxemia in Shamia goats. J Anim Vet Adv. 2007;6:768-772.

29. Antunovic Z, Speranda M, Steiner Z. The influence of age and the reproductive status to the blood indicators of the ewes. Arch. Tierzucht Dumm. 2004;47:265-273.

30. Bekeova E, Elecko V, Heindrichovsky J, Choma J, Krajnicakova M. The effect of beta-carotene on the changes in T4 and cholesterol concentrations in calving heifers before and after parturition. Vet Med (Praha). 1987;32:459 -468.

31. Khatun A, Wani GM, Bhat JIA, Choudhury AR, Khan MZ, Biochemical indices in sheep during different stages of pregnancy. Asian J Anim Vet Adv. 2011;6:175-181. 
32. Firat A, Özpinar A. The study of changes in some blood parameters (glucose, urea, bilirubin, AST) during and after pregnancy in association with nutritional conditions and litter size in ewes. Tr J Vet Anim Sci. 1996;20:387-393.

33. Takarkhede RC, Gondane VC, Kolte AY, Rekhate DH. Indian. Vet J. 1999;76 (3):205-207.

34. Seidal H, Novotay J, Kovac C. Selected biochemical indices in sheep during pregnancy and after parturition, Bull Vet Inst Pulway. 2006;50:167-170.

35. Moghaddam G, Hassanpour A. Comparison of blood serum glucose, beta hydroxybutyric acid, blood urea nitrogen and calcium concentrations in pregnant and lambed Ewes. J Anim Vet Adv. 2008;7(3):308-311

36. Hafez AEF, Mahfouz MK, Maksoud HAA. Biochemical Changes in Glutathione Redox System and Glucose Regulation in Late Pregnant Ossimi Ewes. J Am Sci. 2010;6(11):742- 748 .
37. Antunovic Z, Novoselec J, Sauerwein H Speranda M, Vegara M, Pavic V. Blood metabolic profile and some hormones concentration in ewes during different physiological status. Bulgarian J Agri Sci. 2011:17:687-695.

38. Waziri MA, Ribadu AY, Sivachelvan N. Changes in the blood serum proteins, hematological and some blood serum biochemical profiles in the pregnancy stage in the Sahel goats. Vet Archiv. 2010;80:215-224.

39. Kadzere CT, Llewelyn CA, Chivandi E. Plasma progesterone, calcium, magnesium and zinc concentrations from oestrus synchronization to weaning in indigenous goats in Zimbabwe. Small Rum Res. 1996;24:21-26.

40. Georgivskii VI, Annenkov BN, Smomkhin VT. Mineral and Nutritional of animal. London, Bttuer Worths. 1982.

41. Fredeen AH. Van Kessel JS. Effect of sudden loss of Ca resorption in mature sheep. Can J Anim Sci. 1990;70:884-887. 